\title{
Isotopic Signatures as an Indicator of Long-Term Water-Use Efficiency of Haloxylon Plantations on the Dried Aral Sea Bed
}

\author{
Asia Khamzina ${ }^{1, * \mathbb{C}}$, Jiae An ${ }^{2}$, Hanna Chang ${ }^{1}$ and Yowhan Son ${ }^{1}$ \\ 1 Department of Environmental Science and Ecological Engineering, Korea University, 145 Anam-Ro, \\ Seongbuk-Gu, Seoul 02841, Korea; wkdgkssk59@naver.com (H.C.); yson@korea.ac.kr (Y.S.) \\ 2 Division of Restoration Research, National Institute of Ecology, Yeongyang 36531, Korea; jiae_an@nie.re.kr \\ * Correspondence: asia_khamzina@korea.ac.kr
}

Received: 23 November 2019; Accepted: 25 December 2019; Published: 27 December 2019

\begin{abstract}
The desiccation of the Aral Sea due to water withdrawal from contributing rivers has resulted in an unprecedented change in the region's climate, from maritime to hot dry desert. Afforestation has been implemented on the desiccated seafloor-the Aralkum Desert-for stabilizing the exposed substrate. However, studies on the long-term status of the afforested sites are limited. Here, we examined $\mathrm{C}$ and $\mathrm{N}$ isotopic signatures in Haloxylon aphyllum plantations, as indicators of time-integrated plant response to the prevalent water and salinity constraints, in northern Aralkum, Kazakhstan. Foliar ${ }^{13} \mathrm{C}$ composition analysis in a chronosequence of $\mathrm{H}$. aphyllum plantation sites (aged 1-27 years) on the sandy substrate revealed a significant trend towards higher water-use efficiency in older plantations, possibly in response to declining water availability. A lack of correlation between plant ${ }^{13} \mathrm{C}$ signature and soil electrical conductivity suggests no history of salt stress despite the saline environment. Furthermore, ${ }^{15} \mathrm{~N}$ enrichment in plant tissue in the water-limited Aralkum ecosystem indicates the relative openness of $\mathrm{N}$ cycling. There was an increase in species richness and self-propagation at the plot scale, indicating successful afforestation effort. Coupled with other approaches, isotope discrimination might elucidate mechanisms underlying stress tolerance in H. aphyllum, which could support the afforestation efforts.
\end{abstract}

Keywords: afforestation; Aralkum; Central Asia; saksaul; ${ }^{13} \mathrm{C} ;{ }^{15} \mathrm{~N}$

\section{Introduction}

The desiccation of the Aral Sea due to withdrawal of water from the contributing rivers has resulted in a significant change in the region's climate, from maritime to dry hot desert, with irreversible consequences for the regional ecosystems and local livelihoods [1-3]. Afforestation has been implemented on the dried seafloor, the man-made Aralkum Desert, for stabilization of the exposed substrate, in order to prevent soil erosion, salty dust storms, and adverse effects on human health. The newly vegetated areas also hold potential for carbon sequestration, foraging, and wildlife conservation [1,4]. Black and white saksaul species (Haloxylon spp.), native to the central Asian deserts, have been the pioneering species in the afforestation efforts dating to the late 1980s and more recent decades. Several studies have evaluated the phytoremediation potential of Haloxylon spp. in test sites at the crucial stage of plantation establishment [5-7]. However, studies addressing the long-term development of vegetation are limited, and they have mostly focused on natural succession in various exposed substrates [1,7] and the spatial dynamics of vegetation cover [8]. Long-term development and sustainability of afforested plots have eluded attention, often due to limited feasibility for conducting field studies in remote locations with lacking research infrastructure for continuous measurement of soil-plant-atmosphere dynamics. 
Stable carbon $(\mathrm{C})$ and nitrogen $(\mathrm{N})$ isotopic signatures of plants and soils can serve as tracers that indicate time-integrated responses of plants to the environmental constraints [9,10]. These indicators are thus suitable for a rapid assessment of environmental influences, that is, water and salinity constraints prevalent in Aralkum, on plant functions that cannot be easily measured or surmised from yield data alone. Rainfall variability is considered the most significant factor affecting the $\mathrm{C}$ and $\mathrm{N}$ isotopic composition in dryland plants [11,12]). A low soil water potential due to dryness decreases intercellular $\mathrm{CO}_{2}$ concentration through stomatal closure, resulting in ${ }^{13} \mathrm{C}$ enrichment in the foliar tissue. The plant $\mathrm{C}$ isotopic composition $\left(\delta^{13} \mathrm{C}\right)$ is also positively related to the intrinsic water-use efficiency (WUE, the ratio of water loss to biomass gain), because a decrease in water availability induces stomatal closure thereby enhancing the WUE [9]. Similarly, soil salinity is found to be correlated with $\delta^{13} \mathrm{C}$ because salinity-induced water stress, due to a lower water potential of saline soils and thus reduced water uptake by the roots [13], reduces stomatal conductance and consequently increases intrinsic WUE. Natural abundance of ${ }^{15} \mathrm{~N}$ in plants and soils can be used as an indicator of $\mathrm{N}$ cycling in an ecosystem [14], but the interpretation of ${ }^{15} \mathrm{~N}$ signatures is more complex as they reflect the net result of a range of processes [10].

In this study, we conducted a preliminary evaluation of the long-term status of afforested sites using stable $\mathrm{C}$ and $\mathrm{N}$ isotopic signatures as indicators of plant vigor in response to the prevalent water and salinity constraints in Aralkum. The specific objectives of our study were as follows: (i) examining the range of ${ }^{13} \mathrm{C}$ and ${ }^{15} \mathrm{~N}$ signatures in plant communities of Haloxylon-based afforestation series in northern Aralkum, (ii) assessing long-term variations in $\delta^{13} \mathrm{C}$ and $\delta^{15} \mathrm{~N}$ in the afforestation chronosequence sites, and (iii) interpreting the observed variations in relation to the plant water status.

\section{Materials and Methods}

The study area in northern Aralkum covers about $9600 \mathrm{~km}^{2}$ of $44.822^{\circ} \mathrm{N}$ and $45.741^{\circ} \mathrm{N}$ latitude and $60.014^{\circ} \mathrm{E}$ and $61.332^{\circ} \mathrm{E}$ longitude (Figure 1). The area has been entirely desiccated since about 1977.

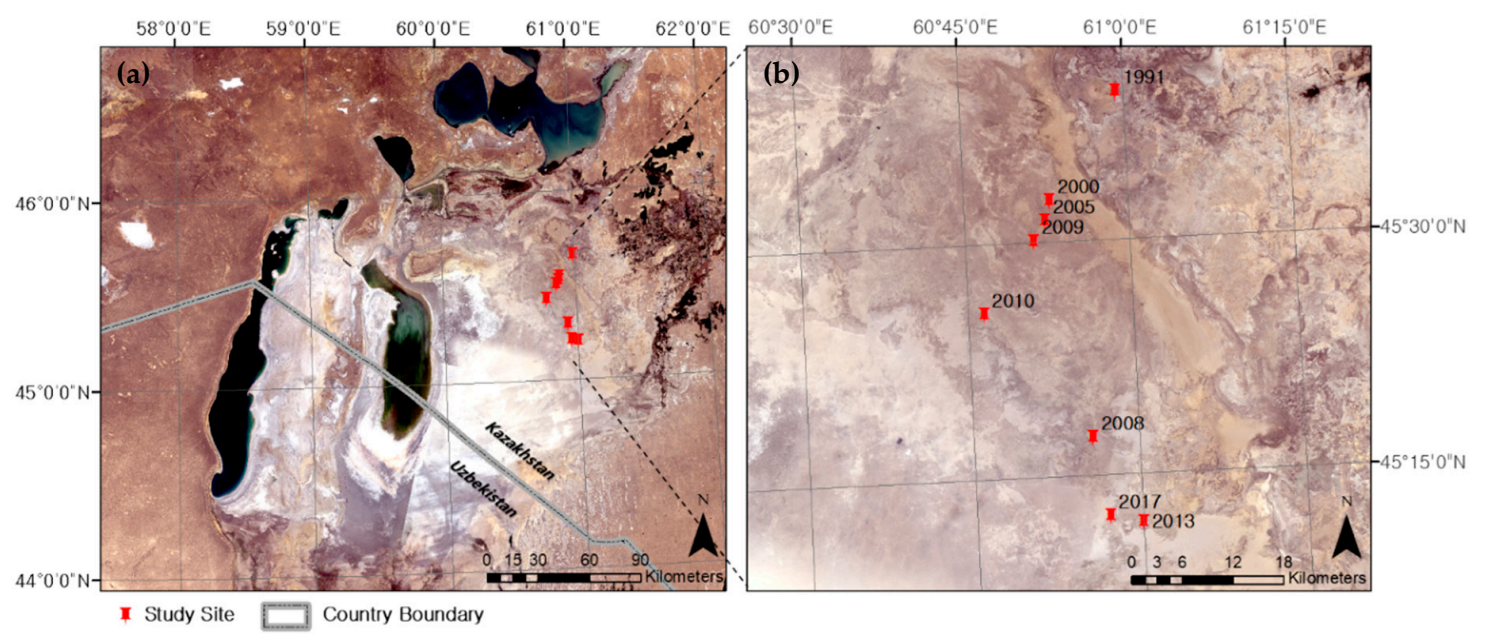

Figure 1. Study area in northern Aralkum, Kazakhstan (a) and locations of the surveyed afforestation sites (b). Source: Landsat-8 OLI acquired on 17-31 August 2018. WGS 1987 UTM Zone 40N.

Afforestation sites of different establishment ages were selected for reconstructing the pattern of plant development and responses to environmental constraints. Seven afforestation sites established during 1991-2017 (Table 1) by planting seedlings or seeds (only in 1991) of Haloxylon aphyllum were surveyed on 20-21 August 2018. These plantations were set up on typical barren plain areas characterized by a sandy substrate (sand fraction $=90 \%$ ) with remnant seashells. In most of the sites that we visited, the original stand density and plant age distribution were significantly altered by both mortality and self-propagation of Haloxylon plants. Three sampling plots of size $30 \mathrm{~m} \times 44 \mathrm{~m}$ were delineated randomly in each plantation site, and then $H$. aphyllum individuals were counted and the 
presence of any plant species besides $H$. aphyllum was examined. Sun-exposed photosynthetic tissues (foliage and green shoots) were sampled from the outer surface of the crown at approximately $1.5 \mathrm{~m}$ above the ground in three randomly selected individuals of $H$. aphyllum and each of the co-occurring species (Table 1). The samples were collected into zip-bags and transported in a cool box to the laboratory, where they were dried at $60^{\circ} \mathrm{C}$ and finely ground.

Table 1. Plant species identified in August 2018 in the northern Aralkum sites afforested with Haloxylon aphyllum during 1991-2017 (plantations aged 1-27 years).

\begin{tabular}{|c|c|c|c|c|}
\hline Number & Family & Species & $\begin{array}{c}\text { Common or Local } \\
\text { Name }\end{array}$ & $\begin{array}{c}\text { Year of } \\
\text { Afforestation }\end{array}$ \\
\hline 1. & Amaranthaceae/Chenopodiaceae & $\begin{array}{l}\text { Haloxylon aphyllum (Minkw.) } \\
\text { Iljin. (Synonym: Haloxylon } \\
\text { ammodendron (C.A.Mey.) }\end{array}$ & Black saksaul & $\begin{array}{c}1991,2000,2005, \\
2008,2009,2010, \\
2013,2017\end{array}$ \\
\hline 2. & Amaranthaceae & $\begin{array}{l}\text { Halocnemum strobilaceum } \\
\text { (Pall.) Bieb }\end{array}$ & Sarsazan & $\begin{array}{c}\text { 1991, 2005, 2009, } \\
2017\end{array}$ \\
\hline 3. & Amaranthaceae & Atriplex fominii Iljin. & Lebeda, Olabuta & 2013,2017 \\
\hline 4. & Asteraceae & Karelinia caspia (Pall.) Less. & Ak-bash & 1991,2005 \\
\hline 5. & Asteraceae & Artemisia diffusa $\mathrm{H}$. Krasch. & $\begin{array}{c}\text { Common } \\
\text { wormwood }\end{array}$ & 1991 \\
\hline 6. & Tamaricaceae & Tamarix hispida Willd. & Russian tamarisk & 2005,2017 \\
\hline 7. & Fabaceae & Alhagi maurorum Medik. & Camelthorn & 1991 \\
\hline 8. & Solanaceae & Lycium ruthenicum Murray & Karamik & 1991 \\
\hline
\end{tabular}

The concentration and isotope ratios of $\mathrm{C}$ and $\mathrm{N}$ were determined using a continuous-flow stable isotope ratio mass spectrometer (IsoPrime VisION-EA; Isoprime, Manchester, UK) coupled with a CNS analyzer (Elementar Group, Hanau, Germany). Each sample was processed in duplicates. A multiple replicate analysis indicated that standard deviations of the $\delta^{13} \mathrm{C}$ and $\delta^{15} \mathrm{~N}$ values were $<0.1 \%$ and $<$ $0.2 \%$, respectively. The $\mathrm{C}$ and $\mathrm{N}$ isotope compositions $\left(\delta^{13} \mathrm{C}\right.$ and $\left.\delta^{15} \mathrm{~N}\right)$ were calculated as follows:

$$
\Delta(\%)=\left[\left(R_{\text {sample }} / R_{\text {standard }}\right)-1\right] \times 1000
$$

where, $R$ is the ratio of ${ }^{13} \mathrm{C} /{ }^{12} \mathrm{C}$ or ${ }^{15} \mathrm{~N} /{ }^{14} \mathrm{~N}$; the V-PDB (available from the IAEA) standard was used in C analysis and atmospheric $\mathrm{N}_{2}$ values in the $\mathrm{N}$ analysis. A simple linear regression analysis was applied to reveal the significance of temporal trends in the isotopic signatures across the afforestation series.

\section{Results and Discussion}

The stand density of $H$. aphyllum varied between 66 and 164 individuals per hectare, with the highest density in the older sites. Including H. aphyllum, eight plant species belonging to five families were identified in the afforested sites (Table 1), which corresponded to the species richness observed in the later successional stages (20-30 years) in naturally vegetated sandy areas in northern Aralkum [6]. In three of the eight sites, no other species besides $H$. aphyllum was detected, however the current vegetation inventory was restricted by the sampling plots' area visited once during late summer.

The species might have been introduced unintentionally during the afforestation activity with Haloxylon and/or their seeds dispersed by wind after or before afforestation. Halocnemum strobilaceum and Atriplex fominii, both belonging to the same family as H. aphyllum (Amaranthaceae), were recorded in four and two of the eight sites, respectively. The oldest plantation (year 1991) was most species-rich and characterized by the relatively dense stand. The presence of several individuals of Tamarix hispida, the only other woody species, in two sites (dated to 2005 and 2017) signifies a shallower groundwater table that favored the establishment of this obligate phreatophyte in the sites [15].

Carbon concentration in the photosynthetic organs ranged from $29.5 \%$ in $\mathrm{H}$. strobilaceum to $44.4 \%$ in Artemisia diffusa across the sites (Figure 2a). The average foliar C concentration in H. aphyllum plants 
was $34.1 \% \pm 0.6 \%$ across all sites. The $\delta^{13} \mathrm{C}$ values for Amaranthaceae family members were in a narrow range-from $-12.5 \%$ in $\mathrm{H}$. aphyllum to $-15.5 \%$ o in A. fominii (Figure $2 \mathrm{~b}$ ). This range suggests the $\mathrm{C}_{4}$ photosynthetic pathway $[9,16]$ in all these species. The $C_{4}$ plants tend to show lower transpiration rates and higher intrinsic WUE relative to those of the $C_{3}$ plants. The other species exhibited significantly more negative $\delta^{13} \mathrm{C}$ values, ranging from $-24.8 \%$ o to $-28.2 \%$, which is consistent with those in $\mathrm{C}_{3}$ plants [9]. The relatively lower $\delta^{13} \mathrm{C}$ in $A$. diffusa suggests its greater WUE among the $C_{3}$ plants.

(a)

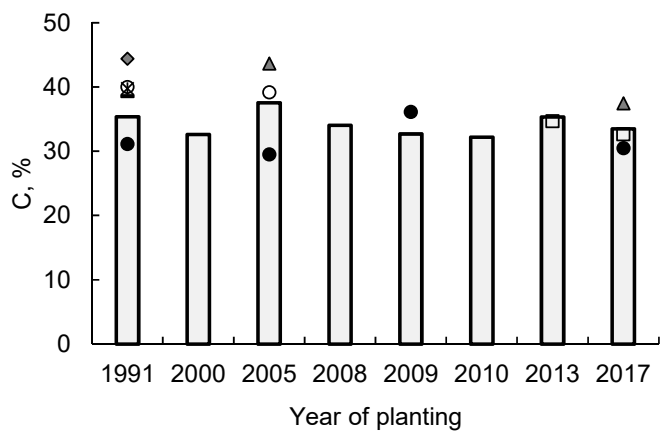

(b)

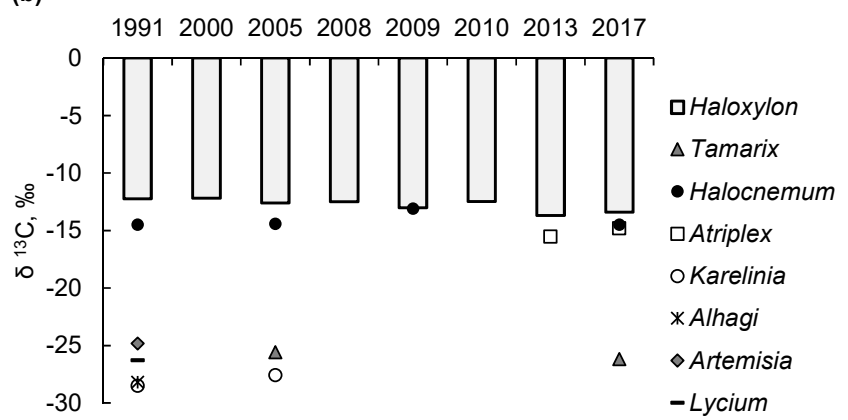

Figure 2. Carbon concentration (a) and $\delta^{13} \mathrm{C}(\mathbf{b})$ in photosynthetic organs of plant species identified in the northern Aralkum sites afforested with Haloxylon aphyllum during 1991-2017 (plantations aged 1-27 years).

The average ${ }^{13} \mathrm{C}$ signature of $H$. aphyllum $(-12.8 \pm 0.2 \%$ o) is higher than that reported by Su et al. [17] and Zhao et al. [16] in native stands of this species in northwestern temperate deserts of China $(-14.3 \%$ o and $-14.1 \%$, respectively). The observed value is close to $-12.4 \pm 0.5 \%$ o exhibited by $H$. aphyllum plantings under high salinity conditions in the Kyzylkum Desert [18]. The less negative ${ }^{13} \mathrm{C}$ values of H. aphyllum in Aralkum indicate the higher WUE. In general, the less negative the $\delta^{13} \mathrm{C}$ value of a plant, the higher the WUE, provided that comparisons are made among plants that are exposed to similar environmental conditions [9]. In this respect, it is recommended to estimate the long-term WUE of plants in the Central Asian desert using ${ }^{13} \mathrm{C}$ composition in the photosynthetic organs sampled between late August and late September [17], thus integrating the responses accumulated throughout the growing season.

The significant temporal trend of $\delta^{13} \mathrm{C}$ in the afforestation series, towards less negative values from seedlings to mature plants, indicates that the plant WUE increased over time (Figure 3a). The ability of non-phreatophytic H. aphyllum to maintain sufficient water supply to the foliage is attributed to the efficient morphological adjustment of the rooting systems and to the strong stomatal control $[15,19]$.
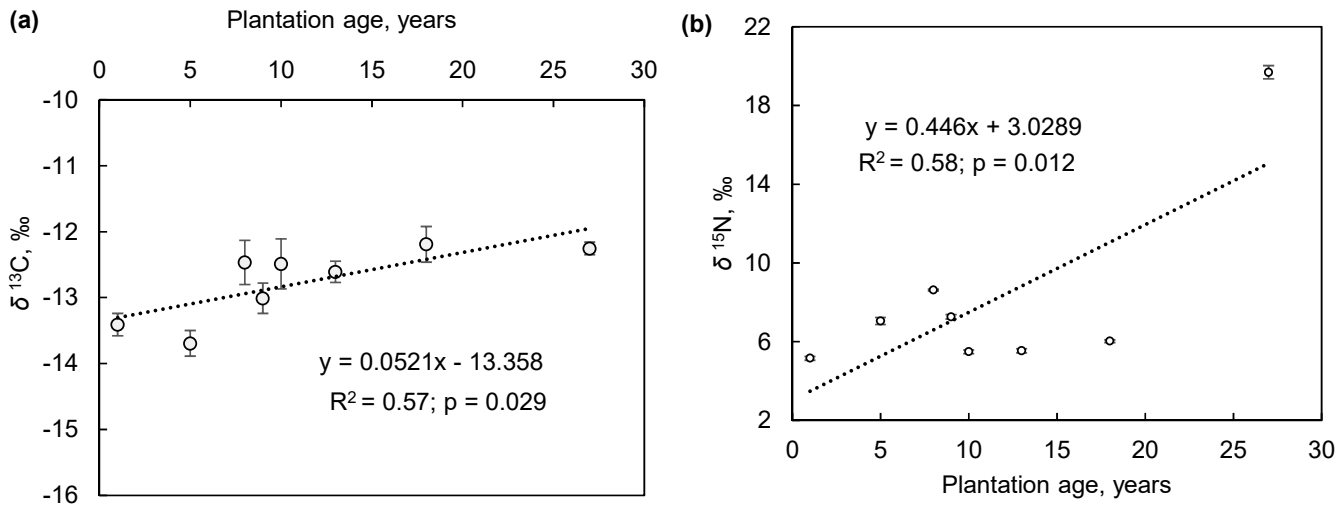

Figure 3. Temporal trends of $\delta^{13} \mathrm{C}(\mathbf{a})$ and $\delta^{15} \mathrm{~N}(\mathbf{b})$ in photosynthetic organs of Haloxylon aphyllum plants in afforestation chronosequence sites (1991-2017; plantations aged 1-27 years) in northern Aralkum. 
Given the correlation between plant $\delta^{13} \mathrm{C}$ and atmospheric precipitation in drylands [10-12,14], the enrichment of foliar tissue with ${ }^{13} \mathrm{C}$ might reflect the decline in rainfall and/or decreasing water availability for plant communities in mature Haloxylon stands. The ${ }^{13} \mathrm{C}$ composition of $\mathrm{C}_{4}$ plants is considered to be less sensitive to the precipitation gradient than that of $C_{3}$ plants (e.g., [12] in the Mediterranean), but several studies (e.g., [14] in northern China) demonstrated a significant enrichment of ${ }^{13} \mathrm{C}$ in $\mathrm{C}_{4}$ plants in response to decreasing rainfall.

Besides declining water availability, elevated soil salinity levels can also increase the ${ }^{13} \mathrm{C}$ values of H. aphyllum, as observed in the Central Asian Kyzylkum Desert [18]. Carbon isotopic signature acts as an integrated indicator of stress history rather than a snapshot in time, as shown by higher isotopic values in plant tissues developed after salinization [20]. The increase in $\delta^{13} \mathrm{C}$ in the Haloxylon afforestation chronosequence sites (Figure $3 \mathrm{a}$ ) did not conform to the temporal trend of the soil electrical conductivity $\left(\mathrm{EC}_{1: 5}\right)$, thus rebuffing a history of salinity stress. The variations in soil $\mathrm{EC}_{1: 5}$, between 8-21 dS m ${ }^{-1}$, point to the overall strong degree of soil salinity and thus reveal significant salt tolerance of H. aphyllum, in line with the assessment by Matsuo et al. [18]. Shrubs of T. hispida showed a similar ${ }^{13} \mathrm{C}$ composition in the leaves at two sites where soil salinity differed by more than two-fold ( 8.7 and $21 \mathrm{dS} \mathrm{m}^{-1}$ in sites dating to 2005 and 2017, respectively), confirming the halophytic characteristics of this $C_{3}$ species $[15,18]$.

The changes in $\delta^{15} \mathrm{~N}$ in soils and plants along natural precipitation gradients can be used to identify the pattern of $\mathrm{N}$ losses relative to the turnover among the sites [6]. An enrichment of ${ }^{15} \mathrm{~N}$ can signify the loss of $\mathrm{N}$ as it discriminates the heavier ${ }^{15} \mathrm{~N}$ isotope, favoring a larger proportional loss of ${ }^{14} \mathrm{~N}$ and increasing $\delta^{15} \mathrm{~N}$. The generally high, positive values of ${ }^{15} \mathrm{~N}$, ranging from $5.2 \%$ o to $19.7 \%$ o (Figure $3 b$ ), were within the upper range or exceeded the values reported along the precipitation gradient in northern China [14] and eastern Mediterranean [12]. This suggests a more open N cycling in the water-limited and soil erosion-prone Aralkum ecosystem [1], resulting in generally higher values and a tendency for enrichment of foliar ${ }^{15} \mathrm{~N}$ over time (Figure $3 b$ ). However, various soil processes influence the plant ${ }^{15} \mathrm{~N}$ signatures and can be responsible for higher $\delta^{15} \mathrm{~N}$ in plants in water-stressed environments [10], which requires further investigation.

\section{Conclusions}

Increasing species richness and evidence of self-propagation observed at the plot scale indicate the successful afforestation effort in northern Aralkum. Foliar ${ }^{13} \mathrm{C}$ composition in H. aphyllum in a chronosequence of afforestation sites (aged 1-27 years) exhibited a significant temporal trend towards higher WUE in older plantations, possibly in response to declining water availability. A lack of correlation between plant isotopic signatures and soil $\mathrm{EC}_{1: 5}$ suggested no history of salt stress despite the elevated soil salinity. Furthermore, ${ }^{15} \mathrm{~N}$ enrichment in plant tissue in the water-limited Aralkum ecosystem indicates the relative openness of $\mathrm{N}$ cycling. Stable $\mathrm{C}$ and $\mathrm{N}$ isotopic composition in the Haloxylon afforestation chronosequence sites helped to rapidly assess time-integrated plant responses to the prevalent environmental constraints in the Aralkum ecosystem. Coupled with other approaches, isotope discrimination might help elucidate the mechanisms underlying WUE and salt tolerance in Haloxylon, which could support the afforestation efforts.

Author Contributions: Conceptualization, A.K. and Y.S.; methodology, A.K.; formal analysis, A.K.; investigation, A.K., J.A., H.C.; writing-original draft preparation, A.K.; writing-review and editing, A.K., Y.S., J.A., H.C.; visualization, A.K.; supervision, A.K.; project administration, H.C. and J.A.; funding acquisition, Y.S. All authors have read and agreed to the published version of the manuscript.

Funding: This study was supported by the Biodiversity Fund of Kazakhstan and Korea Forest Service (South Korea).

Acknowledgments: We thank the colleagues of Kazalinsk Forestry Department in Kazakhstan for the dedicated support during the field survey, Hyun-Woo Jo of Korea University for the assistance in map preparation, and Lee Heng of the International Atomic Energy Agency (IAEA) for the advice on isotopic analyses.

Conflicts of Interest: The authors declare no conflict of interest. 


\section{References}

1. Breckle, S.W.; Wucherer, W.; Dimeyeva, L.; Ogar, N. Aralkum-A Man-Made Desert. The Desiccated Floor of the Aral Sea (Central Asia); Springer: Berlin/Heidelberg, Germany, 2012.

2. Roy, S.B.; Smith, M.; Morris, L.; Orlovsky, N.; Khalilov, A. Impact of the desiccation of the Aral Sea on summertime surface air temperatures. J. Arid Environ. 2014, 110, 79-85.

3. Ayzel, G.; Izhitskiy, A. Climate change impact assessment on freshwater inflow into the Small Aral Sea. Water 2019, 11, 2377. [CrossRef]

4. Orlovsky, N.; Birnbaum, E.H. The role of Haloxylon species for combating desertification in Central Asia. Plant Biosyst. 2002, 36, 233-240. [CrossRef]

5. Novitskiy, Z. Phytomelioration in the Southern Aralkum. In Aralkum-A Man-Made Desert. The Desiccated Floor of the Aral Sea (Central Asia); Breckle, S.-W., Dimeyeva, L., Wucherer, W., Ogar, N.P., Eds.; Springer: Berlin, Germany, 2012; pp. 387-406.

6. Wucherer, W.; Breckle, S.-W.; Kaverin, V.S.; Dimeyeva, L.A.; Zhamntikov, K. Phytoremediation in the Northern Aralkum. In Aralkum-A Man-Made Desert. The Desiccated Floor of the Aral Sea (Central Asia); Breckle, S.W., Wucherer, W., Dimeyeva, L., Ogar, N., Eds.; Springer: Berlin/Heidelberg, Germany, 2012; pp. 343-386.

7. Breckle, S.-W. From Aral Sea to Aralkum: An ecological disaster or halophytes' paradise. In Progress in Botany; Lüttge, U., Beyschlag, W., Francis, D., Cushman, J., Eds.; Springer: Berlin/Heidelberg, Germany, 2013; Volume 74, pp. 351-398.

8. Löw, F.; Navratil, P.; Kotte, K.; Schöler, H.F.; Bubenzer, O. Remote-sensing-based analysis of landscape change in the desiccated seabed of the Aral Sea-A potential tool for assessing the hazard degree of dust and salt storms. Environ. Monit. Assess. 2013, 185, 8303-8319. [CrossRef] [PubMed]

9. Pate, J.S. Carbon isotope discrimination and plant water-use efficiency. In Stable Isotope Techniques in the Study of Biological Processes and Functioning of Ecosystems; Unkovich, M., Pate, J.S., McNeill, A., Gibbs, D.J., Eds.; Springer: Berlin/Heidelberg, Germany, 2001; pp. 19-36.

10. Dawson, T.E.; Mambelli, S.; Plamboeck, A.H.; Templer, P.H.; Tu, K.P. Stable isotopes in plant ecology. Annu. Rev. Ecol. Evol. Syst. 2002, 33, 507-559. [CrossRef]

11. Swap, R.J.; Aranibar, J.N.; Dowty, P.R.; Gilhooly, W.P.; Macko, S.A. Natural abundance of ${ }^{13} \mathrm{C}$ and ${ }^{15} \mathrm{~N}$ in $\mathrm{C}_{3}$ and $\mathrm{C}_{4}$ vegetation of Southern Africa: Patterns and implications. Glob. Chang. Biol. 2004, 10, 350-358. [CrossRef]

12. Hartman, G.; Fanin, A. Isotopic values of plants in relation to water availability in the Eastern Mediterranean Region. Oecologia 2010, 162, 837-852. [CrossRef] [PubMed]

13. Munns, R. Plant adaptations to salt and water stress: Differences and commonalities. In Advances in Botanical Research; Kader, J.-C., Delseny, M., Eds.; Elsevier: Amsterdam, The Netherlands, 2011; Volume 57, pp. 2-32.

14. Ma, J.-Y.; Sun, W.; Liu, X.-N.; Chen, F.-H. Variation in the stable carbon and nitrogen isotope composition of plants and soil along a precipitation gradient in northern China. PLoS ONE 2012, 7, e51894. [CrossRef] [PubMed]

15. Xu, H.; Li, Y.; Xu, G.; Zou, T. Ecophysiological response and morphological adjustment of two Central Asian desert shrubs towards variation in summer precipitation. Plant Cell Environ. 2007, 30, 399-409. [CrossRef] [PubMed]

16. Zhao, D.; Cheng, J.; Liu, Y.; Liu, L.; Li, R.; Sheng, J. Relationship of stable carbon isotope composition with environmental factors in the desert plant, Haloxylon ammodendron. Acta Ecol. Sin. 2017, 37, 2743-2752.

17. Su, P.-X.; Liu, X.-M.; Zhang, L.-X.; Zhao, A.-F.; Li, W.-R.; Chen, H.-S. Comparison of $\mathrm{d}^{13} \mathrm{C}$ values and gas exchange of assimilating shoots of desert plants Haloxylon ammodendron and Calligonum mongolicum with other plants. Isr. J. Plant Sci. 2013, 52, 87-97. [CrossRef]

18. Matsuo, N.; Ojika, K.; Shuyskaya, E.; Radjabov, T.; Toderich, K.; Yamanaka, N. Responses of the carbon and oxygen isotope compositions of desert plants to spatial variation in soil salinity in Central Asia. Ecol. Res. 2013, 28, 717-723. [CrossRef] 
19. Gintzburger, G.; Toderich, K.N.; Mardonov, B.K.; Mahmudov, M.M. Rangelands of the Arid and Semi-Arid Zones in Uzbekistan; CIRAD ICARDA: Montpellier, France, 2003; p. 431.

20. Poss, J.A.; Gratten, S.R.; Suarez, D.L.; Grieve, C.M. Stable carbon isotope discrimination: An indicator of cumulative salinity and boron stress in Eucalyptus camaldulensis. Tree Physiol. 2000, 20, 1121-1127. [CrossRef] [PubMed] 